\title{
MEDIEVAL PREPARATIONS OF URINARY STEROID HORMONES
}

by

\author{
LU GWEI-DJEN AND JOSEPH NEEDHAM
}

(References indicated by superior figures are to the Chinese characters opposite pages I 18 and I19.)

\section{Introduction}

OUR knowledge of the endocrine functions of the sexual organs of man and mammals is an acquisition of comparatively recent date. Endocrinology as a whole indeed does not go back beyond the beginning of the present century. By the end of the twenties a great deal of important knowledge about the endocrine secretions of the testis and ovary, the placenta and the adrenals had been attained, as may be seen in the collective work Sex and Internal Secretions, edited by Edgar Allen in 1932. The same period had seen the establishment of the correct formula of the steroid ring system by Wieland, Windaus, Diels, Bernal, Rosenheim and King; and this opened the way for the sweeping advances in the field of androgens and oestrogens which have taken place since then.* We are now familiar with a large number of substances of androgenic and oestrogenic activity naturally occurring in the body, and we are also able to make use of derivatives of these substances which do not naturally occur in Nature but which may have very useful properties for our purposes.

Since the knowledge of the steroid sex hormones is thus such a characteristic achievement of modern science, it seems hardly believable that in any phase of ancient or medieval science it should have been possible to make preparations which possessed activity of this kind. Nevertheless, we have recently come upon a corpus of material which indicates that this was accomplished by the Chinese iatro-chemists between the tenth and the sixteenth centuries A.D. Guided by theories of traditional Chinese type, not of course the same as those of modern science, and using urine as their starting-point, they succeeded in preparing mixtures of androgens and oestrogens in relatively purified form and employing them in medicine. The classical discovery of Aschheim \& Zondek in 1927 that pregnancy urine contains rich amounts of steroid sex hormones, $\dagger$ and the subsequent discoveries of the presence of similar substances in urine from other sources, was thus anticipated by many centuries in these Chinese empirical preparations. In the present paper we wish to set forth the evidence which we have found. $\neq$

\footnotetext{
* On the androgens see especially Dorfman \& Shipley.

† It very soon became the chief source of supply for biochemists; cf. Veler \& Doisy's paper, and Allen, pp. 440, 483; also Brooks et al., p. III.

¥ The system of romanization of Chinese characters in this paper follows that of Wade-Giles with the substitution of an ' $h$ ' for the aspirate apostrophe.

We are greatly indebted to Dr. Roger Short of the Department of Veterinary Science at Cambridge and to Dr. Hal Dixon of the Biochemical Department, as well as to Prof. H. Breuer, for much kind help and valuable advice.

We wish to record with great gratitude generous financial assistance received from the Wellcome Trust.
} 


\section{Lu Gwei-Djen and Joseph Needham}

\section{The Sexual Organs in Chinese Medicine}

Before proceeding further it will be desirable to say a few words about the sexual organs in Chinese medical thought and practice. The secondary sexual characteristics were recognized as connected with the testis in quite ancient times. As in all other civilizations, castration was undertaken very early, in man for social reasons (eunuchism), and in animals both for medicinal purposes and for gastronomy, because gelded animals were found to put on fat and to give a more tender meat. The simple physiological experiment of castration thus taught the Chinese very early that the beard and other characters of virility were connected in some way with the presence of the testes. Intersexes also aroused much interest and were catalogued in the Hsi $\mathrm{Yuan}_{\mathrm{Lu}}{ }^{1}$ of Sung Tzhu, ${ }^{2}$ the founder of forensic medicine, in A.D. 1247. This book, entitled The Washing Away of Wrongs (i.e. False Charges), is the oldest treatise on legal medicine in any civilization, and it was natural that attention should be paid in it to various forms of hermaphroditism.* By the sixteenth century A.D., Li Shih-Chen ${ }^{3}$ in his great pharmacopoeia, the Pên Tshao Kang $\mathrm{Mu}^{4}$ (1596), has an elaborate discussion of ten principal forms of hermaphroditism. $\dagger$ The interest of the Chinese was aroused very early also in sex-reversals. From the beginning of the Former Han dynasty (third century B.c.) cases are reported, for example in the Lun Heng ${ }^{5}$ (Discourses Weighed in the Balance) $\ddagger$ of the famous sceptic Wang Chhung, ${ }^{6}$ written about A.D. 80. These sex-reversals, where persons predominantly male turned into persons mainly female in character and vice versa, were taken note of naturally for prognostication purposes, like other unusual phenomena, celestial or terrestrial. For this reason many cases of similar change in animals as well as man were recorded in the dynastic histories under the heading of 'strange events'; $\S$ and there are plenty of case reports in the memorabilia of private scholars.

So far as we know, the Chinese were not particularly early in the use of testicular tissue as a therapeutic agent in cases of hypo-gonadism, sexual debility, impotence, spermatorrhoea, and female affections such as dysmenorrhoea, leucorrhoea, etc. The practice was first emphasized in a book entitled Lei Chêng Phu Chi Pên Shih Fang 10 (Classified Fundamental Prescriptions of Universal Benefit) printed in A.'.o. I 253, and attributed to an eminent physician, Hsü ShuWei, ${ }^{11}$ who flourished in A.D. I I 32. The testes of animals such as the sheep, pig and dog were used either desiccated, raw or comminuted with hot wine. Other thirteenth-century books describe the treatment, e.g. the Chi Sêng Fang ${ }^{12}$ (Prescriptions for the Preservation of Health), written by Yen Yung-Ho' ${ }^{13}$ about 1267; after that time it became a current method in Chinese therapeutics. I The use of testis tissue as a drug goes back far in medical history; it appears in

* Chap. 1, pp. $32 a$ ff. The material was in part older, since Sung Tzhu based his work on three still earlier books now lost.

$\dagger$ Chap. 52, pp. 43aff. Hereinafter abbreviated to PTKM. Study continues today in China on modern lines; cf. Liu Pên-Li et al.

$\mp$ Chap. 7 (Forke tr., vol. r, p. 327).

\$ E.g. Chhien Han Shu, ${ }^{7}$ chap. 27 BA, pp. $20 a f f$; chap. 27 GA, p. $18 b$; Hou Han Shu, ${ }^{8}$ chap. 27, p. 8a; Hsin Thang Shu,' chaps. 34 to 36 passim.

\|Cf. Laufer. Further references will be given in "Science and Civilization in China" (hereinafter abbreviated to SCC), vol. vi.

T See PTKM, chap. 50A, pp. 13a, $21 a, b, 30 b, 43 a$. 


\section{Medieval Preparations of Urinary Steroid Hormones}

the Hippocratic corpus, in Dioscorides (c. A.D. 6o), ${ }^{*}$ and among the Indian writings, especially the Susruta-samhita, some time between the second and fifth centuries A.D. $\dagger$ As early as I 35 B.C. Nicander recommended the use of the testes of hippopotamus. $\neq$ There is no reason to think that such medication would have been valueless. Although testosterone is inactivated in the liver, administration per os may have been reasonably effective, provided sufficient quantities were given to the patient.

Chinese medicine was perhaps more original in the use of the human placenta for therapy; after all the richest source of oestrogens. § How far back this goes we are not quite sure, but $\mathrm{Li}$ Shih-Chen tells us $\|$ that the use of human placenta was first mentioned in the Pên Tshao Shih $I^{14}$ pharmacopoeia written by Ghhen Tshang-Chhi15 about A.D. 725. At first it was not greatly used, but during the Ming period (fourteenth century onwards) it came into prominence, and was prescribed habitually for all such affections as are considered to benefit by the administration of oestrogens at the present day. The placenta was much studied by Wu Chhiu ${ }^{16}$ towards the end of the fifteenth century in his Chu Chêng Pien $I^{17}$ (Resolution of Diagnostic Doubts); he, like other physicians of the Yuan and the Ming, invariably prescribed placental tissue, desiccated or boiled down

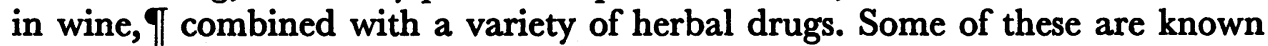
today to have quite powerful effects on smooth muscle, blood-pressure, etc.** The oral route is often considered inefficient for oestrogens, but there can be no doubt that real effects would have been produced if enough material was given. $\dagger \dagger$ As in the case of the testis, placentas of animals, especially the horse and cat, were also employed. $+\ddagger$

One little indication occurs here which links the use of the placenta with the iatro-chemical studies on urine which are the main subject of this paper. In discussing the placenta, $\mathrm{Li}$ Shih-Chen quotes first from a Tan Shu ${ }^{20}$ concerning the theory of the use of the placenta and the choice of the best specimens for the purpose. It is probable that Tan Shu here is a generic term meaning books on iatro-chemical medicines, and not the name of a specific work, for it cannot be found in Li Shih-Chen's own bibliography.|||| If this is so, there is here an interesting link with the iatro-chemists, descendants of the alchemists of the Thang and Sung who developed the urinary fractionation methods now to be discussed.

* Gunther ed. p. 102; Berendes, vol. 1, pp. 194, 294; Brooks et al., p. 23.

$\dagger$ Bhishagratna ed., vol. II, pp. $512 \mathrm{ff}$. $\ddagger$ Berendes, vol. I, p. 274 .

$\|$ PTKM, chap. 52, pp. $36 a, b, 37 a, b$.

§ Allen, p. 456 .

II Such a treatment, like refluxing with aqueous alcohol, would liberate the steroid hormones, both free and conjugated, from the cells.

* E.g. tu-chung ${ }^{18}$ (Eucommia ulmoides), and tang-kuei ${ }^{10}$ (Angelica polymorpha).

$\dagger \dagger$ Oestrogenic components can in certain circumstances be well absorbed per os (cf. Allen, pp. 908, 910); progesterone not so. The famous experiments of Brown-Sequard in 1889 , so often regarded as the foundation of endocrinology, sought to overcome the difficulties of the oral route by the injection of glycerol extracts of testis tissue; they were thus distinctly less subtle than the ancient Chinese methods of fractionating urine, and indeed also less convincing, since "the validity of the results has not been substantiated' (Allen, p. 88I), while the Chinese preparations were in widespread use.

$+\ddagger$ PTKM, chap. $50 \mathrm{OB}$, p. $20 a$; chap. $51 \mathrm{~A}$, p. $36 b$.

Iili A search in the catalogues of the Taoist Patrology (Tao T sang) ${ }^{21}$ which contains so many alchemical books, reveals only one which contains both these characters in its title, a Tan Tao Pi Shu ${ }^{22}$ (Secret Book of the Tao of Elixirs); but this is not in either of the main collections, and we have not been able to see it. We suspect that it is in any case a late work, and not what $\mathrm{Li}$ Shih-Chen was referring to. 


\section{Lu Gwei-Djen and Joseph Needham}

\section{Proto-Endocrinology in Chinese Medical Theory}

Elsewhere we expect to give a thorough study of the theories of Chinese physiology, pathology and medicine throughout antiquity and the Middle Ages.* These are the basis of the characteristic conceptions of traditional Chinese medicine still today. Our conviction is that such an extended study will demonstrate that the Chinese medical theory-structure was remarkably congruent with the fundamental conception of endocrinology, namely that the organs of the body exert important effects upon one another.

In the first place, the principal viscera were analogized with the elements. As is generally known, Chinese natural philosophy from the fourth century B.c. onwards thought in terms of five elements (unlike the Greek four): Metal, Water, Wood, Fire and Earth. $\dagger$ The whole of Nature was considered as being the theatre of a continual succession of changes in the Five Elements, changes which proceeded according to certain systems of mutual inter-relations. One such system was the Mutual Production Order, a particular succession according to which each element generated the next one in a series. Similarly, another cyclical succession was that known as the Mutual Conquest Order, in which in a different succession each element conquered or destroyed its neighbour, according to a particular succession. Since the viscera were analogized with the Five Elements the conception of constant interactions between them lay very near to the physiological thought of the ancients.

Besides the Five Elements, however, there were also the two fundamental forces in the universe, Yin and Yang, originally corresponding to brightness and darkness, the male and the female, etc., but here particularly relevant in that the physiological thinkers used them so often in a sense very similar to that which we have in mind when we speak of stimulus and inhibition. Thus the medieval Chinese physicians had no difficulty in conceiving of a stimulatory action of one organ on another and also an inhibitory one.

Furthermore, there was a third feature in classical Chinese physiological thought which helped the conception of interactions within the body as a whole. This is what one might call a circulation-mindedness. Although medieval Chinese physiology had no such precise conception of a circulation of the blood in the blood-vessels as was brought to perfection by William Harvey, nevertheless it did not share in the old Greek and medieval Western ideas of 'tides' in the blood. Chinese thought envisaged a steady circulation throughout the body of $c h i^{23}$ (pneuma) and blood. blood had indeed been appreciated as early as the Former Han period, when the Huang $\mathrm{T}_{i} \mathrm{Nei}$ Ching, ${ }^{24}$ the earliest medical classic, was compiled.\$ Consequently it was not only easy on general element-theory to imagine the action of one organ upon another, but it was also easy to see how it could come about because of the perpetual circulation going on within the body.

* SCC, vol. vr.

† See SCC, vol. II, pp. 232 ff., $253 \mathrm{ff}$.

¥ As yet there is no adequate treatment of this subject in a Western language, but we intend to give one in SCC, vol. vi; meanwhile the reader may be referred to the papers of Liang Po-Chhiang; Kapferer; and Huard \& Huang Kuang-Ming.

\$ The locus classicus is Ling Shu, ${ }^{26}$ chap. 39; cf. also Su Wên, ${ }^{20}$ chaps. 27, 39. 


\section{Medieval Preparations of Urinary Steroid Hormones}

In 1849 A. A. Berthold* made his classical experiment of transplanting the testis in the cock to the abdominal cavity; he found that it was vascularized but not innervated in its new position, and he was thus able to prove that the caponized cock would remain a cock, a fully male animal, when the testis was able only to contribute something to the blood-stream. The thought behind Berthold's experiment-the foundation of modern endocrinology, though not followed up for sixty years afterwards $\uparrow$-has been investigated by Forbes, but it still remains somewhat obscure. It probably originated from the old Greek theory of pangenesis, according to which particles from all the organs of the body went to form the corresponding organs in the embryo. $\neq$ As interpreted in the eighteenth century by men such as Maupertuis, Buffon and de Bordeu, $\S$ this theory supposed that every organ (even if it had an obviously external secretion also) contributed specifically and characteristically to the bloodstream, not only for the purpose of forming the sexual products but also for all kinds of purposes. This then was probably the mainspring of Berthold's experiment. Knowing the relation of the testes to the secondary sexual characteristics, he thought that it might be possible to demonstrate that their action was mediated by the blood-stream alone. And it was. From what has been said above it will be clear that the implicit content of the medieval Chinese medical conceptions was rather similar, in that the Five Viscera were in constant communication with each other through the circulatory systems of the body.\|

What was particularly remarkable about the Chinese practices from the tenth century A.D. onwards was the fact that they based themselves on the belief that the contributed 'virtues' of the blood were in part transmitted to the urine. The urine could therefore be regarded as a valuable source of some of these precious qualities. The traditional doctrine of Chinese medicine is summed up by Li Shih-Chen in his Pên Tshao Kang Mu (1596), where he says that the nutrient essentials ( $j e n$ chih ching chhi ${ }^{27}$ ) circulating in the body divide into two fractions, the lighter fraction (chhing chế ${ }^{28}$ ) forms the blood, and the grosser fraction (cho $c h \hat{e}^{20}$ ) forms the chhi; then the grosser part of the lighter fraction forms the urine, while the lighter part of the grosser fraction forms the secretions. For this reason the urine must be considered as 'of the same category as' (thung $l e^{30}$ ) the blood. This was a fundamental doctrine, for the conception of categories was of wide-ranging implication in Chinese medieval natural philosophy. Elsewhere we have studied the doctrine of categories in relation with medieval Chinese alchemy, where it was also highly important. I Essentially it provided a further cross-classification other than the basic division of all things and events in the world into Yin and Yang. A multitude of texts bear witness that particular processes will only occur if the reacting substances are either of the same or of a different category, but knowledge of the categories one must have.

* Biography by Rush.

† The converse demonstration with the ovary was due to Knauer and Halban-but not till 1900 .

$\ddagger$ Cf. Needham, pp. 39 ff.; Meyer, pp. $86 \mathrm{ff}$.; Russell. The theory, characteristic of the Hippocratic and Democritean schools, was combated by Aristotle.

$\$$ See Neuburger; Rolleston. PEC.

II For the wider aspects of medieval Chinese proto-endocrinology, see Needham \& Lu Gwei-Djen, I See Ho Ping-Yü \& Needham: CAT. 


\section{Lu Gwei-Djen and Joseph Needham}

The use of the urine as a starting-point for medicinal preparations can therefore in no way be dismissed as merely superstitious 'Dreckapotheke'. On the contrary, there was good theoretical ground for it in medieval Chinese eyes, and it is remarkable to reflect how far this intuition has been justified by the assured findings of modern biochemical science. Moreover, it is clear that what the Chinese were looking for in urine was a substance or substances which would give the kind of results that the androgens and oestrogens give when administered today. This will be apparent from the quotations of texts given below.

\section{The Empirical Background}

The use of urine as a medicament, especially for sexual debility and related disorders, goes back a very long way in Chinese history. The Hou Han Shu (History of the Later Han dynasty) has a short biography of three Taoist adepts who lived towards the end of the second century A.D. It must be remembered that the attitude of ancient Taoism to sex was philosophical and medicoscientific rather than ascetic in the ordinary Western sense. Among the paths to the attainment of material immortality, sexual techniques took their place beside diet, gymnastic exercises, control of the breathing, heliotherapy and ascesis as understood in the West. The passage is as follows:*

Kan Shih"1 and Tungkuo Yen-Nien"2 [Comm. The Han Wu Nei Chuan ${ }^{23}$ (Secret History of (Emperor) Wu of the Han) says that his (Tungkuo's) style was Kung-Yuse.] and Fêng Chün$\mathrm{Ta}^{25}$ these three were all adepts (or magicians, fang shih ${ }^{30}$ ). They were all expert at following the techniques of Jung Chheng" in commerce with women. ${ }^{2}$ They could also drink urine and sometimes used to hang upside down. They were careful and sparing of their seminal essence and (inherited) chhi, and they did not boast with great words of their powers. What Kan Shih, (Tso) Yuan-Fang ${ }^{8 \%} \neq$ and (Tungkuo) Yen-Nien could do was recorded by (Tshao) Tshao ${ }^{20}$ who asked them about their art and tried to practise it.§

[Comm. Tshao Chih's'0| Pien Tao Lun'1 (On Taoism, True and False) says: 'Although Kan Shih was old, yet he looked young. All the magicians and adepts flocked to him, but he talked much and showed them little. His words were unorthodox and strange. I myself once dismissed my retainers and talked alone with him, asking him with kindness and courtesy what exactly it was that he practised. He said "My teacher's name was Han Ya. ${ }^{42}$ With this master I once made gold in the southern regions; on four occasions we threw away into the sea several tens of thousands of catties of gold." He also said "In the time of (Shen) Chu-Liang ${ }^{43}$ (i.e. 500 B.c.) I barbarians came from the western regions bringing tribute of incense, Kashmir cloth belts and jade-cutting knives; I often regretted that I did not get some of them." He also said "In the countries west of the Chü-Shih" kingdom, people cut open the backs of new-born children and take out their spleens in the hope that they will eat less and be more aggressive."** He also said "If you take a pair of carp (fishes) five inches long, put a certain drug into one of

* Chap. 112B, p. $18 a$.

$\dagger$ A semi-legendary figure associated both with sexual physiology and calendrical science. Cf. van Gulik.

$\ddagger$ Alchemist and thaumaturgist, A.D. 155 to 220 or a little later. Like the other three, a frequenter of the court of the founder of the (San Kuo) Wei Kingdom.

8 The founder, and posthumously the first emperor, of the (San Kuo) Wei Kingdom; celebrated as a military leader, and interested in many aspects of technology.

\| Third son of Tshao Tshao, famous writer and poet, much inclined to Taoism and interested in natural history.

TI A sympathetic feudal lord with whom Confucius once conversed when on his travels, builder of one of the most ancient of Chinese reservoir dams for irrigation water.

** The Han histories describe two Chü-Shih kingdoms, one anterior and one ulterior (from the Chinese point of view), the former centred on Turfan, the latter on Guchen, but both in modern Sinkiang. See Teggart, p. 212; McGovern (under Güshî). 


\section{Medieval Preparations of Urinary Steroid Hormones}

them and throw it into boiling fat, the drug will make it violently move its tail and gills and leap about wildly up and down as if it were sporting in the abyss. But by this time the other one will be cooked and can be eaten." I often asked him whether (these things) could be tested. He said that this drug was ten thousand miles away and one must go beyond the frontiers to get it. "If you don't go yourself", said he, "you won't get it." (Kan Shih) said many other things but I cannot recall them all; I mention only the strangest. If he had lived in the time of Chhin Shih Huang ${ }^{45}$ or $\mathrm{Han} \mathrm{Wu} \mathrm{Ti}^{46}$ he would have been counted among (the great adepts such as) Hsü Fu'7 and Luan Ta. ${ }^{48}$ "*

Fêng (Chün-Ta) was called the Blue Ox Master (Chhing Niu Shih" ${ }^{49}$ ). [Comm. The Han Wu Nei Chuan says that he was a Kansu man. He began by eating huang-lien ${ }^{50} \dagger$ and after more than fifty years he entered the Niao-Chü Mountains ${ }^{\mathrm{BO}}$ and consumed metallic mercury. After more than a hundred years he returned to his native village looking like a young man of twenty. He always rode on a blue ox, which was why he was called the Blue Ox Taoist. If he heard of anyone who was ill or dying, whether he knew him or not, he quickly gave him drugs, which he kept in a tube of bamboo tied to his waist. Sometimes he practised acupuncture on the patients, who incontinently recovered, but he never revealed his names. He heard that Lu Nü-Sêng ${ }^{51}$ had got hold of the Five-Mountain Map, and year after year he asked for it but he could never obtain it. ( $\mathrm{Lu})_{\ddagger}^{+}$would only counsel moderation. When he was over 200 years old he (Fêng) went away into the Yuan-Chhiu Mountains.]

The association of urine with sexual activity therefore goes back to a very early time in Chinese history, and if here we find it towards the end of the second century A.D. it is highly probable that it was a Taoist art which could be found in the second century B.c. also. Jung Chhêng, the semi-legendary master of the arts of sex and hygiene applied to longevity, was considered a man of this time if not of the Warring States period (fifth to third centuries B.c.). The connection with alchemy is here of course very evident and impressive. The curious legendary adumbration of endocrinological operations is entertaining in the context of Berthold's discovery, but hardly relevant, except in so far as it may indicate physiological experimentation on the part of the Han Taoists. The case of Fêng Chün-Ta also illuminates the intimate relations between Taoism and medicine.

A thousand years later one comes across the same belief and practice. Ghu Chen-Hêng ${ }^{52}$ says in his Pên Tshao $Y_{e n} I P u I^{53}$ (Revision and Amplification of the General Ideas of the Pharmacopoeia), written about A.D. I350:§

I once attended an old woman over eighty years of age who gave an appearance of being about half that seniority. In reply to my questioning she explained why she thought she had had such good health. She had once suffered from a severe illness and had been instructed to take human urine, and this she had done for more than forty years. Who could maintain therefore the old belief that the property of urine is algorific, and that it could not be taken for a long time? All such cases of yin hsü ${ }^{64}$ (impotence, sexual debility, eremosis, excess Yang of burning feverish type, etc.) which no medicine can benefit will take a turn for the better if urine is administered.\|

\footnotetext{
* Chhin Shih Huang Ti was the first emperor of China unified under the first dynasty, the Chhin (r. 221 to 210 B.c.); he sent Hsü Fu to find the isles of the immortals in the Eastern Ocean. Han Wu Ti was the greatest of the Han emperors (r. I4I to 87 B.c.); he was served by many Taoist adepts, among whom Luan $\mathrm{Ta}$ is remembered for his connection with the history of magnetical science; cf. SCC, vol. rv, pt. I.

$\dagger$ Coptis tecta, a very bitter herb.

$\ddagger$ Another of Tshao Tshao's thaumaturgical experts.

8 Chu Chen-Hêng (1280 to $135^{8}$ ) was one of the 'four famous physicians of Chin and Yuan'.

II Quoted in PTKM, chap. 52, p. I5a. Some of the technical terms in this passage (and in those which follow) have been developed by us to aid in the translation of medieval Chinese medical texts, and will be fully explained in SCC, vol. vi.
} 


\section{Lu Gwei-Djen and Foseph Needham}

An intermediate date is represented by Chhu Chhêng, ${ }^{55}$ a physician who died in A.D. 50I. In his remaining writings we read that the urine is valuable because it has styptic properties.

When the throat has lesions, the patient coughs up blood and this may lead to death. The throat will not tolerate anything on its walls, so that an object as tiny as a hair will cause a severe cough. The more the coughing continues the worse the breathing will be, so that it is essential to stop it. If urine is taken the condition is nearly always cured, but if algorific drugs are given none of the patients gets better.*

We do not know what property of urine such styptic effects could be due to, but there can be no doubt that throughout the centuries between Kan Shih and Chu Chen-Hêng urine was used medicinally. Li Shih-Chen says that it has the property of leading forth from the body pathological influences.

Human urine is moderately calorigenic and not algorific. Urine entering the stomach is absorbed, carried upwards to the lungs along with the pneuma of the spleen (phi chih chhi ${ }^{\text {b7 }}$ ), and downwards to the 'water-passage' (shui ${ }^{200^{58}}$ ) to enter the urinary bladder. $†$ This is the same route through which it passed once before. For this reason it can lead the (undue) heat (yin huos9), the cause of the illness, downwards to be excreted. $\ddagger$

In the light of all this it was perfectly natural that the sediments and natural precipitates of the urine should arouse great interest among the Chinese medical naturalists at an early time. While it seems that the appearance of the urine was never rated so highly for the purposes of diagnosis as it was in the West, $\$$ nevertheless it was thought that the sediments might contain very important substances. The naturally occurring sediment was called ni pai hsin ${ }^{60}$ or jen chung $p a i,{ }^{61}$ and the first evidence of its use occurs in the Thang period. Li Shih-Chen says that it was first mentioned in the Thang Pên Tshao, ${ }^{62}$ and though this is not extant today, we can confirm what he says by the manuscript of the Hsin Hsiu Pên Tshao ${ }^{63}$ (Newly Reorganized Pharmacopoeia) || of A.D. 659, which was conserved in Japan. The reference to ni pai hsin is there very clear. Possibly the earliest account of its use, in this case for curing severe diarrhoea in infants, occurs in the Chhien Chin Yao Fang ${ }^{64}$ (Thousand Golden Remedies) by the great Sui and Thang physician Sun Ssu-Mo about A.D. 650. In the fourteenth century Chu Chen-Hêng said that the

urinary precipitate has the property of leading out the (undue) heat affecting the liver, the three coctive regions (san chiao ${ }^{\circ 5}$ ), and the bladder, by way of the urine. This is because it was itself originally excreted through the bladder and urinogenital tract. $\mid$

Li Shih-Chen in the sixteenth century repeats the statement.** He says that

* Chhu Chhêng I Shuse, cit. PTKM, chap. 52, p. 16a.

† On p. 15a the 'water passage' is identified with the lan mên, ${ }^{882}$ a structure which we recognize as the colic valve at the junction of the ileum with the caecum and colon. Here the intestinal contents were thought to separate into two portions, the aqueous part passing to the kidneys and the bladder, while the solid residues continued towards the anus. The work of concentration of the contents was thus symbolically located at a particular place.

\$Fr a brief account of ancient and medieval urinoscopy see Mettler, pp. $293 \mathrm{ff}$.

i| Chap. 15, p. 189 .

I PTKM, chap. 52, p. I9a.

$\ddagger$ Loc. cit.

108 


\section{Medieval Preparations of Urinary Steroid Hormones}

jen chung pai makes the hsiang huose (primary heat)* descend, and disperses static blood. This is because of its saline property which enables it to benefit the hsia (chiao ${ }^{\text {sea }}$ ) (lower coctive region) and to travel along with the blood.

Thus we have another principle, that of yin $\operatorname{tao}^{67}$ leading something out by the same way that it previously came itself. This brings us to the purification of the urinary precipitates. Who would guess that one would have to look for them in the Chinese pharmacopoeias under the names of chiiu shih ${ }^{68}$ (autumn mineral) and chhiu ping ${ }^{69}$ (autumn ice, i.e. crystals)? $\dagger$

\section{The Iatro-Chemical Preparations}

Writing about A.D. I $^{86,} \mathrm{Li}$ Shih-Chen tells us that urinary precipitate can

keep the blood in motion, greatly help sexual debility, bring down heat, kill parasites, and disperse poisons; but the princes and wealthy patricians disliked using it because they considered it unhygienic. So the iatro-chemists ( fang shih) began to purify the sediment, making first chhiu shih and later on chhiu ping. For this they used two methods, the Yang lien ${ }^{70}$ and the Yin lien. ${ }^{11}+$

According to $\mathrm{Li}$ Shih-Chen the term chhiu shih was first mentioned in the Pên Tshao Mêng Chhïan ${ }^{22}$ (Ignorance about the Pharmacopoeia Dissipated) produced by Chhen Chia-Mo ${ }^{73}$ in A.D. 1567. Chhen Chia-Mo emphasized the value of the product in many sexual and systemic disorders. However, $\mathrm{Li}$ goes on to say:

The term was really first used by the Huai $\mathcal{N a n} T z u^{74}$ book. $\left(\right.$ (Liu An ${ }^{742}$ ) named one of his elixirs (tan) chhiu shih, to express its white colour and its solidity. Recently people have purified the urinary precipitates (jen chung pai) to a white substance which is also called chhiu shih, to indicate that like the urine itself it is derived from the excess of the nutrient essentials (ching chhi). The iatro-chemists repeat the process of sublimation (sheng $\mathrm{ta}^{75}$ ), and the best product is called chhiu ping. The idea (of the initial concentration) was derived from the evaporation of sea-water in the production of salt. Indeed there are adepts who place (certain) salts in the reaction-vessel and apply heat to obtain a substitute or imitation product. It is important to know the difference between the real product and the false one.

One of our most important sources for the preparation of the hormones in

* This term usually refers to the heat of the cardiac region, but it is also applied to that of the urinogenital system (cf. SCC, vol. rv, pt. 1, p. 65). In Chinese medical literature, heat, fire and Yang are interchangeable.

+ There can be little doubt that the name derives from the fact that a long process gave rise to a white product, for autumn is the climax of the yearly cycle of life and white was the colour of autumn in the system of symbolic correlations (cf. SCG, vol. II, pp. 262, 263, and vol. Iv, pt. I, p. I I). Modern Western students of Chinese materia medica have had a tradition of translating it simply as 'urea', but in the light of the evidence here presented, this is quite untenable. Smith's explanation (1871, p. 224) made clear that the product as he knew it was simply the total urinary solids, but Giles' dictionary (1892, no. 2302), adopted the bald identification, and so did Read (1931, no. 419), who ought to have known better. Curiously Smith adds that the substance is 'often kept in kitchens, to soften fresh meat required for immediate use', for it.is indeed true that strong urea solutions denature proteins and bring them into solution.

+ PTKM, chap. 52, p. $20 b$.

$\S$ This work is one of the great classics of Chinese history of science; it was compiled about 125 B.C. by a group of naturalists gathered by Liu An, the Prince of Huai-Nan. There is no mention of chhiu shih in the text as we have it today; a solitary reference to 'autumn drugs' occurs in chap. 19, p. 14 $b$, but it has to do with something else. 


\section{Lu Gwei-Djen and Joseph Needham}

relatively purified form is a book called the Shui $Y_{u ̈ n} L_{u^{76}}$ (Water and Clouds Record) by a famous scholar, Yeh Mêng-Tê77 (A.D. 1077 to I I 48). Another work of about the same time refers to the preparations, namely the So Sui $\mathrm{Lu}^{\mathbf{7 8}}$ (Fragments from the Ring of Jade) by an unknown author, probably of the late eleventh century. This work says:

The property of chhiu shih is saline; it travels (in the body) along with the blood. When taken it has the effect of reducing the (normal) equilibrium of Water over Fire, i.e. it weakens the renal-urinogenital system so that it cannot balance the cardiac-respiratory system. So continual use of the substance gives rise to pathological thirst.*

\section{After quoting this, Li Shih-Chen goes on to say:}

This is because it is a processed product with properties verging on the calorific. It is often taken by lascivious people, who use it to further their unrestrained desires; the result is that eremotic heat (hsï $\mathbf{r}_{\text {ang }}{ }^{782}$ ) is set at large, and the renal-urinogenital system and the seminal secretion (chen shuivo) quite exhausted. How could there not be thirst in such conditions? Besides people sometimes add Yang (calorific) drugs to intensify the aphrodisiac effect (hsieh huo ${ }^{702}$ ). Therefore only those who suffer from internal eremotic algor in the umbilical region and impotence (tan thien hsü lêng ${ }^{80}$ ) should take it. Look at those suffering from urinary gravel and stone; in such patients the element of Water is weak and Fire is very strong, so naturally there is evaporation and precipitation with the formation of calculi. This occurs by exactly the same principle as is used in making chhiu shih from urine.

Here we have a strong indication that the products which were available in $\mathrm{Li}$ Shih-Chen's time, as also apparently in the Sung, were of considerable hormonal activity, even though perhaps this was difficult to control. His acute account of the formation of urinary calculi is worth notice in passing. $\dagger$ The Shui Yün Lï says that:

The best preparations are the products of two different processes of purification, one Yin and one Yang. The rang lien $\neq$ process is designed to obtain the Yin concealed in the Yang, for it condenses as heat is applied (in evaporation). It dissolves in water (a Yin entity) and returns to formlessness $\left(w u t h i^{81}\right)$, yet it retains its special properties $\left(w e i^{82}\right)$. It is like the broken line in the $k u a \mathrm{Li}^{82 a} . \S$

The Yin lien $\|$ process is designed to obtain the Yang concealed in the Yin, for

it precipitates when water is added to it. When dried in the sun it becomes glossy and changes no more. In this case the (original) special properties (wei) are lost and the substance (chih ${ }^{83}$ ) remains. It is like the solid line in the kua Khan ${ }^{82 a}$. I

Both substances came originally from the heart and the renal-urinogenital system (including the sex organs) yet had once been flowing in the small intestine. ... To take these substances can be beneficial for those two systems (or organs), indeed they are the essentials for the maintenance of a healthy life. ...**

* PTKM, chap. 52, pp. $20 b, 21 a$.

$\dagger$ Gallstones and bezoars were instanced as examples of the concretive or aggregative forces in nature by the Neo-Confucian philosophers in Sung times, when discussing the formation and dissipation of souls; cf. Wieger, p. 215. $\mp$ The text says huo lien, ${ }^{80 a}$ but the meaning is the same.

8 One of the symbolic trigrams in the 'Book of Changes' (see SCC, vol. II, p. 313).

II The text says shui lien, ${ }^{\circ \mathrm{Bb}}$ but the meaning is the same.

TI One of the symbolic trigrams in the 'Book of Changes' (see SCC, vol. Ir, p. $3^{13}$ ).

* PTKM, chap. 52, p. $21 a, b$. 


\section{Medieval Preparations of Urinary Steroid Hormones}

We come now to a description of the six main preparation methods given in the Pên Tshao Kang Mu.

\section{Method I}

This method is the simplest as it is the oldest. It is quoted by Li Shih-Ghen from a Ching Yen Liang Fang ${ }^{84}$ (Valuable Tried and Tested Prescriptions). There were several books of this name in the Yuan and early Ming periods (fourteenth and fifteenth centuries), one by Lü Shang-Chhing, ${ }^{85}$ and we do not know from which of them $\mathrm{Li}$ Shih-Ghen took his account. However, it is possible to show that the method goes back much earlier than this, because the Chhung Hsiu Chêng-Ho Chêng Lei Pên Tshao ${ }^{86}$ (Reorganized Pharmacopoeia) of A.D. 1249 quotes it* from a Ching Yen Fang ${ }^{87}$ (Tried and Tested Prescriptions) of still earlier date. Although this book is lost, the details of its publication are known. $\dagger$ Its preface dates it at A.D. 1025 and its author was Chang Shêng-Tao. ${ }^{88}$ Other prescriptions of this physician, restorative for people on the point of death, are quoted in various editions of the Hsi Yuan Lu. Since Ghang ShêngTao flourished at the beginning of the eleventh century, it is very probable that his method for making chhiu shih was already quoted in the first edition of the Chêng Lei Pên Tshao issued by Thang Shen-Wei ${ }^{89}$ in 1 r 08.

The title of the method is Chhiu Shih Huan Yuan Tan.90 Its description is as follows:

... Take ten $\tan ^{01}$ or more (over 150 gallons) $\ddagger$ of men's urine and put it in a large evaporating pan $\left(k u 0^{92}\right)$ in an empty room. Fix on top of it a deep earthenware still (shen wa ching ${ }^{93}$ ) and lute them together with paper, lime and straw, so that no steam comes out when it has dried. Fill the evaporating basin 70 per cent or 80 per cent full with urine and heat from below. Set a man to watch it. If (there is too much, then) gradually add cold urine, until dry. This (residue) is jen chung pai. Place some of this in a (closed) container (a reaction-vessel, i.e. the $k u$ chi ${ }^{9}$ apparatus, ju hao kuan tzu nei, ju fa ku chiss) in a stove and heat with charcoal. About 2 or 3 ounces (of sublimate) will be obtained. Grind this to a powder, mix with dates, to make pills the size of a mung (lu tou) ${ }^{96}$ bean. $\S$ For each dose take five to seven pills with warm wine or soup before breakfast. . . . II

Here then the entire dried solids of the urine were used. Besides the obvious urates, uric acid, phosphates, sulphates and other inorganic salts, there would be the steroid glucuronides and sulphates. After the simple procedure of evaporation, the entire fatty powder is placed in the sublimatory and the active steroids carefully sublimed. It is a well-known fact that hormones of the steroid class sublime unchanged below their melting-points, at temperatures varying between $130^{\circ}$ and $210^{\circ} \mathrm{C} .{ }^{* *}$ and there can be no doubt that this was the

* Chap. I 5, p. 365 .

† See Okanishi Tameto, pp. 972, 1138.

¥ Weights and measures changed considerably through Chinese dynastic history, but their movements are well enough charted. The volume measure tou, sometimes translated peck, has often been loosely rendered gallon (as in Giles' dictionary) because it comprised ten shêng ${ }^{91 a}$ or 'pints', but in fact the absolute value of the 'pint' varied greatly in different centuries (see Wu Chhêng-Lo, Table I3, p. 58). Here we are concerned with the Sung and Ming periods; in the former the tan of ten tou was equivalent to 14.5 of our gallons, in the latter to 23.6 gallons.

$\$$ Phaseolus mungo, the mung bean, or gram.

il PTKM, chap. 52, p. $21 a$.

** See Kassau; Breuer \& Kassau. Up to $260^{\circ} \mathrm{C}$. there is no decomposition at all, and many compounds will still sublime almost without loss up to $300^{\circ}$. 


\section{Lu Gwei-Djen and Joseph Needham}

technique employed, because the term $k u c h i$ is found in alchemical and technological writings with the meaning of sublimatory.* Since the entire solids of the evaporated urine were taken for sublimation, the process must have been rather a messy one, and it is not surprising that in the following centuries various methods of preparation were worked out which got rid of many of the urinary constituents before sublimation was attempted. This we shall see in the following examples.

\section{Method 2}

This method, together with the following one, derives from Yeh Mêng-Tê's Shui Yü $L u$. This is clearly a Sung work, for Li Shih-Chen refers $†$ to its author both under his ordinary name and under his hao or courtesy name, Yeh ShihLin. ${ }^{100}$ Since this scholar was living towards the end of the Northern Sung and through the years of re-establishment of the dynasty in the South after the fall of the capital, Khaifêng, to the Chin Tartars in A.D. I 126, one might be near the truth in dating his prescriptions about A.D. I I IO. He must have been one of the younger members of the entourage of virtuosi of Hui Tsung, the last effective emperor of the Northern Sung, in a court very similar in many ways to that of Rudolf II at Prague later on, or Alfonso el Sabio in Castile at the end of the following century. $\neq$ The first method is entitled Yang Lien Fa. ${ }^{100 a}$

Use over 10 tan of urine (more than 150 gallons) in wooden buckets. For each tan (14.5 gallons) of urine add one bowlful of the juice of soap-beans (tsao chia chih'101). Stir energetically with a bamboo stick hundreds of times. When the precipitate has settled, decant off the clear fluid and keep the precipitate (ni pai $h s i n$ ). Combine all the precipitates (with some liquid) into one bucket, stir as before and allow to settle. Take one or two tou ${ }^{102}$ of the concentrated mixture and filter. Place the precipitate in a kuo (large evaporating basin) and evaporate to dryness. Scrape it out, grind it fine, and take up as much as possible of it by boiling with water. Filter through paper over a bamboo sieve. Again evaporate to dryness and repeat these processes several times until the precipitate becomes as white as snow. Then put it into an earthenware container (sublimatory) (sha ho $k u\left(c^{i 103}\right.$ ), seal tightly and heat until the sublimate condenses. If the heating does not at first complete the sublimation, repeat the process once or twice more until the colour of the product is like that of lustrous jade. Grind this to a fine powder and place it in another container where it should be heated gently for seven days and seven nights. Then take it out and spread it (on paper) laid on the ground, to get rid of the noxious effects due to the heating. Finally mix the powder with dates to make (small) pills the size of a wu(-thung $\left.{ }^{104}\right)$ seed. $\S$ Thirty pills should be taken daily with warm wine before breakfast.\|

Here we have an extraordinarily interesting procedure. It is hard to believe that the use of saponins for preparing steroids could anticipate by so many centuries,

\footnotetext{
* The nomenclature is delicate here, for the term can also mean a still, i.e. a vessel with a side-tube. In Thien Kung Khai $W^{97}$ (The Exploitation of the Works of Nature) by Sung Ying-Hsing ${ }^{98}$ (A.D. 1637) $k u$ chi is clearly a sublimatory for making vermilion (chap. 16, p. 2b) but it is shown near by as a still for distilling mercury (p. $5 b$, descr. p. 2a). The illustration is reproduced in Ho Ping-Yü \& Needham, LEC, Fig. 52, cf. pp. 82 ff., 100 ff. See further Tshao Yuan-Yu, pp. 43, 52 (pp. 78, 85).

$\dagger$ PTKM, chap. 52, pp. 20b, 22a. Chinese literature contains one other book of the same title, by a Ming pharmacist, Yang Po ${ }^{\circ 9}$, but Li Shih-Chen could hardly have been mistaken in a matter of this kind.

† See SCC, vol. rv, pt. 2, pp. 50 I ff., or Needham, Wang \& Price, pp. $124 \mathrm{ff}$.

Sterculia platanifolia, not to be confused with the thung-oil tree Aleurites fordii.

\|) PTKM, chap. 52, p. 2 I $b$.
} 


\section{Medieval Preparations of Urinary Steroid Hormones}

not merely decades, the classical discovery of Windaus in 1909 that digitonin precipitates many sterols quantitatively.* One of those so precipitated, indeed, is an androgen, namely dehydro-epi-androsterone, and we know today that the saponins will precipitate all the $3 \beta$-hydroxy steroids. The precise action of digitonin is well known, but one cannot be so sure about the action of the various saponins contained in the soap-beans from Gleditischia sinensis, the characteristic vegetable detergents used in Ghina for hygienic purposes all through the Middle Ages. $\dagger$ All one can be sure of is that they would precipitate certain varieties of steroids.

Besides the addition of the saponins in this method of Yeh Mêng-Tê, there was also the addition of proteins in the soap-bean juice. This is important because it is known that all urinary steroids will precipitate with the protein precipitate if one is present. This raises the question of the frequency of renal lesions in the population of medieval China. It seems very likely that in every collection of large amounts of urine as described in these preparations one at least of the donors in the batch would quite probably have been excreting some protein, and a small amount would be quite enough to produce the effects of the precipitation of steroids. We suspect that schistosomiasis was widespread in medieval China, and that in itself would be a possible cause of proteinuria. Then there is the extraction of the total precipitate with boiling water. A possible explanation would be that all the conjugated steroids were taken down in the precipitate, but when the protein present was denatured by the boiling water all would come out in the solution except the $3 \beta$ steroids which had been firmly combined with the saponin. We may be here in the presence of an ancient empirical method of partial separation of androgens from oestrogens.

Another feature of this method is of course the complete removal of soluble solids in the urine, such as urea, by the use only of the first precipitate. A great quantity of soluble salts will also be discarded at this stage. One notices too the gradual elimination of the urinary pigments. Finally the reference to the sublimate as resembling lustrous jade is, as already mentioned, a strong indication that the glittering pearly appearance of crystalline steroids was being observed.

\section{Method 3}

This is the second method of Yeh Mêng-Tê in his Shui Yün Lu, dating from about A.D. I I IO. It is called $\mathrm{Yin}_{\text {Lien }} \mathrm{Fa}^{1042}$, and like the previous method refers back to the two types of separation, the theory of which was discussed in the same book (p. I Io above).

To 4 or 5 tan of urine ( 58 to 72.5 gallons) in large earthenware vats add half its volume of rainwater and stir a thousand times. Allow to settle. Discard the clear solution and keep the precipitate (ni pai hsin). Repeatedly wash with rainwater, stir and allow to settle until no disagreeable odour remains and the precipitate resembles putty or face cream (ni fen ${ }^{105}$ ). Let it dry in the sun, scrape it up and grind it. Then mix with milk from the mother of a male baby

* The protective action of cholesterol in saponin haemolysis was thus explained; and the digitonin precipitation method was immediately applied (Windaus, QBC) to the assay of free and esterified cholesterol in biological entities such as the normal or diseased kidney.

† See Needham \& Lu Gwei-Djen, HYG, pp. $45^{8 \mathrm{ff}}$. 


\section{Lu Gwei-Djen and Joseph Needham}

into a paste $\left(\mathrm{kaO}^{106}\right)$ or fatty-like ointment and dry this in very hot sunshine. By this procedure one obtains the life-giving essentials of the sun (thai yang chen chhi ${ }^{107}$ ). Repeat this nine times and then mix with dates to make pills. Twenty of these should be taken at midday with warm wine.*

This is one of the two methods which begins by diluting the urine. It might at first sight be thought possible that this would help to precipitate lipoidal or steroidal constituents, but since the steroids are all in the form of soluble conjugates, it seems unlikely that this would happen. We are not clear as to the purpose of the dilution, but at any rate it would have done no harm, since it would help to remove soluble substances such as urea and salts. In what way the conjugates were got into the precipitate in this method we are not clear. Perhaps the description accidentally omits some protein precipitant. In any case it is interesting that here no sublimation was involved. The fact that the precipitate was of a fatty consistency and taken up in milk fat is also appropriate enough if free steroids were present, but unless the urine sources had included cases of lipuria, such as may occur in diabetes, it is not easy to understand why the eventual precipitate should have been so fatty in nature. One thing at any rate is probable, namely that these two methods of Yeh Mêng-Tê would have yielded different groups of active urinary steroids, perhaps giving another separation of androgens from oestrogens. The fact that one of his methods was considered Yang and the other Yin gives us a rather strong hint that differences of just this sexual nature had in fact been observed by the physicians who used these preparations.

\section{Method 4}

The next two descriptions are taken from two books of formularies of the early Ming period (fifteenth century). They both stem from local surgeries or pharmacies, exactly where in China we do not know. The first, entitled Chhiu Ping 7 u Fên Wan, ${ }^{108}$ from a book called I Chen Thang Ching Yen Fang ${ }^{109}$ (Tried and Tested Prescriptions of the True-Centenarian Hall) was the work of a writer known only to us by his family name, Mr. (or Dr.) Yang. ${ }^{110}$ The text is as follows:

One bucketful each of the collected sediment (ni pai hsin) from the urine of boys and girls (thung nan thung $n \ddot{u}^{111}$ ) is used. $\dagger$ Heat the evaporating pan containing the sediment with mulberry firewood and evaporate until dry. Remove the residue and place it in one bucket of river water. Mix well until as much as possible is dissolved. Filter and evaporate the filtrate. Repeat the same procedure seven times. By then the residue is as white as frost. Next it is usual to collect I catty of the frost-like residue and place it in an earthenware jar. Cover with an iron lid the shape of an oil lamp, and apply salt-mud lute to make it tight. Heat the jar during the space of the burning of three bundles of incense-sticks to sublime (sheng ta) the substance. At this stage you will see that the chhiu shih has become as white as jade. Grind the product and repeat the procedure. Very gradually sponge cold water on to the cover, care being taken in the process, for with too much cooling the product will not volatilize, and with

* PTKM, chap. 52, p. 2 ib.

+ This must mean an initial volume of at least 400 gallons. The age implied here would be, in the most natural acceptation of the text, under about fifteen, for the Nei Ching defines the marriageable age as sixteen for boys and fourteen for girls. But it may mean unmarried or virgin boys and girls in the sense of the usages of the writer's own time, i.e. up to about eighteen or so. 


\section{Medieval Preparations of Urinary Steroid Hormones}

too little cooling it will not condense.* Carry out the process from the chhen double-hour (7-9 a.m.) until the wei double-hour (I-3 p.m.). Then take away the fuel and let the vessel cool. The substance which has collected under the cover is chhiu ping, ice-like (glossy), tasteless and pleasant-smelling. This substance is the (best) pure essence of the chhiu shih. $\dagger$ When taken it is beneficial for the liquid of the renal-urinogenital system, restoring urinary and sexual normality; it fortifies the vital resistance (yruan $\mathbf{r a n g}^{112}$ ) and also drives down the heat which produces phlegm (than huol18) in the thoracic region. The residue is ordinary chhiu shih, saline and bitter in property like burning meat. In this there is some slight benefit when taken.‡

Here again we see processes of purification carried out so that the very soluble substances such as urea and some salts, together with the pigments, are first discarded; and the conjugates then progressively separated from urates, inorganic salts, denatured proteins, etc., less soluble than themselves. The sublimation process is more clearly described and directions are given that the sublimation should be repeated. Apparently some active substances remained in the residue which did not sublime. One assumes that the active steroid conjugates were carried down with small amounts of protein at the beginning of the operation and passed thereafter into the extracts of the successive residues until sublimation.

\section{Method 5}

This method comes from a book of about the same date as the previous formulary. It is entitled Pao Shou Thang Ching Yen Fang114 (Tried and Tested Prescriptions of the Protection of Longevity Hall), the author of which was Liu Sung-Shih.115 The name of the medicament prepared was Chhiu Shih Wu Ching Wan. ${ }^{116}$ The text runs as follows:

Select boys and girls $\S$ free from any illness as the donors of the urine. They should be bathed and their clothes changed. They should be provided with innocuous food and soup, but one should avoid giving them foods with rank and pungent smells, such as leeks, onions, garlic, ginger, etc., or other things which have an acrid property. When sufficient urine, about I tan (23.6 gallons) has been collected from each group in one vat ( $\left.k a n g^{117}\right)$, add half its own volume of water, stir, and collect the precipitate (jen chung pai). Place this in an earthenware reaction vessel (wa kuan 118) from Yang-chheng ${ }^{1182}$. Make the opening airtight with the lute (a mixture of salt and mud) and use iron wire (or netting) to fix it in the stove. Heat during the space of one bundle of incense-sticks, and repeat the heating seven times, securing with fresh wire each time. Then take weighed equal portions (of the sublimate) from the male and female urine precipitates thus treated. Mix and grind together. Dissolve the material in river water and filter through seven layers of paper. Evaporate to dryness and obtain the chhiu shih which is snow-white in colour. Add to this good sweet thick milk and mix. Leave it in the open air to absorb the sun during the daytime and the dew at night, in order to acquire the essence of the sun and the glory of the moon. After it has been dried further add more milk for forty-nine days. Preserve it as an ingredient for prescriptions.\|

Here the directions about the treatment of the urine donors are interesting, and the details of the sublimation are much the same as before. At first sight it seems

* An inversion in the text has been corrected here.

$\dagger$ It will be noticed that the term chhiu ping seems to be reserved for preparations which have sublimed repeatedly.

\pm PTKM, chap. 52, p. $22 a$.

$\$$ See note, p 114 , on this subject.

II PTKM, chap. 52, p. 22b. This method became the most popular one after Li Shih-Chen's own time, for one finds it constantly repeated in pharmacopoeias of the seventeenth and eighteenth centuries. 


\section{Lu Gwei-Djen and Foseph Needham}

surprising that the text should speak of dissolving the sublimate in water, for if this was composed of free steroids it could not go into solution. But it seems likely that while the sulphate conjugation would be broken by the heating, the glucuronide combination would not, and the sublimate would therefore be composed of two parts, one water-soluble and one insoluble. If specific differences existed between the hormones conjugated in different ways, this procedure may possibly have been yet another quasi-empirical fractionation, producing end-products of highly specific properties.

\section{Method 6}

The following description, the last which we shall quote, comes from the Pên Tshao Mêng Chhïan of Chhen Chia-Mo, already mentioned (p. 109), written in A.D. ${ }^{567}$. His description says:

To make chhiu shih specimens of urine of boys* should be collected in the autumn. Add to each earthenware vat (kang) $0.7 \mathrm{oz}$. of powdered calcium sulphate (gypsum, shih kao mo ${ }^{119}$ ). Stir well with a mulberry stick and allow the precipitate to settle. Discard the clear supernatant fluid. Stir again and allow to settle. Repeat this two or three times. Then add to the precipitate one bucket of autumn dew water, stir and allow to settle. Repeat this again several times until the impurities are removed and the precipitate is quite free from any salty taste. Filter the precipitate on heavy paper placed over ashes, and allow it to sun dry. The light clear crystals forming the upper part of the precipitate are collected, and this is chhiu shih, while the lower, grosser layer is discarded. $\dagger$

This seems to be rather a return to the second or blunderbuss method of Yeh Mêng-Tê (Method 3 above). No sublimation process is used, but it is interesting that calcium sulphate is added to begin with, an agent which would probably assist the precipitation of the proteins and the steroid conjugates adsorbed upon them. The procedure seems to end with a manual separation of the lighter from the heavier part of the final precipitate. Chhen Chia-Mo has two curious observations. He says that for male patients specimens from female urine should be used and vice versa. He also criticizes practising physicians $\left(s h i h i^{120}\right)$ of his own time and earlier who collect mixtures of all kinds of urine at any time and precipitate with soap-bean juice, then dry the product and call it chhiu shih. $\mathrm{He}$ regards this as a way of money-making which may have dangerous consequences. For us, however, it is interesting in that it suggests that the saponin method already introduced in the eleventh century must have been used a great deal through the time elapsing between Yeh Mêng-Tê and Chhen Chia-Mo.

\section{Discussion and Conclusions}

From all the foregoing material it is fairly clear that from the eleventh century onwards the Chinese alchemists, physicians and iatro-chemists were earnestly looking in urine for substances of androgenic and oestrogenic property. They had recognized its connection with the blood, and they felt that within it could be found some of the virtues which the organs contributed to the blood

* See note, p. 114 on this subject. † PTKM, chap. 52, p. $20 a$. 


\section{Medieval Preparations of Urinary Steroid Hormones}

circulation. In our opinion they were successful in medieval times in making quasi-empirical preparations of active substances with androgenic and oestrogenic properties.

Of the six methods described herein, four involve a carefully controlled sublimation at temperatures which would very probably have varied between $120^{\circ}$ and $300^{\circ} \mathrm{C}$., in other words, just those which would bring about a sublimation of the steroid hormones. Of course other substances would have sublimed too; for example, cyanuric acid derived from any urea which was still present. Cyanuric acid has no known effect in man but it has been shown to be antimalarial in birds. Uric acid itself would have decomposed, giving rise to ammonia and $\mathrm{CO}_{2}$. The purification from urinary pigments preceded the sublimation, but other substances present in small quantities, such as indole, skatol, mercaptans, volatile fatty acids and non-steroidal phenols, would either have been washed away or may have sublimed with the steroids. Since none of them was in any way toxic that would not matter.

In two of the methods described there is a long series of precipitations and evaporations before the material is brought to the sublimatory. In two cases specific agents, soap-bean saponin and powdered calcium sulphate, are mentioned. The significance of these has already been pointed out, the use of saponin in particular being an extraordinary anticipation of modern practice. Beside these, however, it is highly probable that small amounts of protein were present in the urine, and the precipitation of this, whether by heat or by the gypsum added, would without doubt have carried down the conjugated steroids. The lipoproteins of the soap-bean would have had a similar function. What the object was of the initial dilution recommended in some cases we do not know, but it could have done no harm. The final end-product was no doubt a very mixed one, consisting of steroids from the testis, ovary, adrenal cortex and placenta; and it probably varied in accordance with the exact method of fractionation used.

Some interest attaches to the precise directions about the age and sex of the urine donors. We know today that androgen excretion reaches its maximum in men about the age of twenty-five and in women also, though they excrete a lesser amount. Conversely, maximum excretion of oestrogens occurs in girls before twenty and in boys about eighteen, the latter, however, excreting only about half as much as the former.* The word thung in the descriptions, though originally meaning quite young boys and girls, may well mean here just unmarried youths and girls of about eighteen or so. If maximum yields of the steroid sex hormones were sought, it would have been somewhat quixotic to insist on starting out with urine from boys and girls before puberty.

What is particularly striking is that in one at least of the methods the urine from male and female sources was actually worked up separately and the products later combined in equal proportions. From this it is very reasonable to suppose that the Chinese physicians found, at least in late times, that quite different effects could be produced by using the sublimates in varying proportions, even wholly male or wholly female. One almost expects to find some

* Dorfman \& Shipley, pp. 259, 396ff., $400 \mathrm{ff}$. 


\section{Lu Gwei-Djen and Joseph Needham}

reference to the urine of the mare, that spectacular source of sex hormones.* And indeed it may perhaps have been used for preparing sublimed chhiu ping, for it is in fact listed among the equine products of pharmaceutical value, $\dagger$ though in connection with various other diseases.

All in all, the experimental preparation of mixtures of steroid sex hormones by the Chinese during the Middle Ages and the sixteenth century must surely stand as an extraordinary example of quasi-empirical anticipation of knowledge acquired only in very recent times. When one considers that they totally lacked the powerful methods of separation available today which depend upon the use of many different organic solvents, one feels amazed at the ingenuity with which they mastered their problem. In view of their theoretical presuppositions, one might suppose that it would have been more logical to use blood rather than urine as the starting-point, but here the difficulty of the presence of so much protein would have presented itself acutely, and one may reasonably suppose that while the handling of blood was beyond the powers of the medieval iatrochemists, urine as a starting-point was much more manageable. And so at it they went, with their 200 or 300 gallons, almost on a pharmaceutical manufacturing scale, their evaporating basins, and their clever sublimatories-a brilliant and courageous anticipation of the conscious biochemistry of our own time.

* Brooks, et al., p. III; the classical paper is that of Häussler in 1934.

† PTKM, chap. 50B, p. 23b. Elsewhere there is mention also of the pharmacological use of the urine of the sheep and the cow. 


\section{LIST OF CHINESE CHARACTERS}

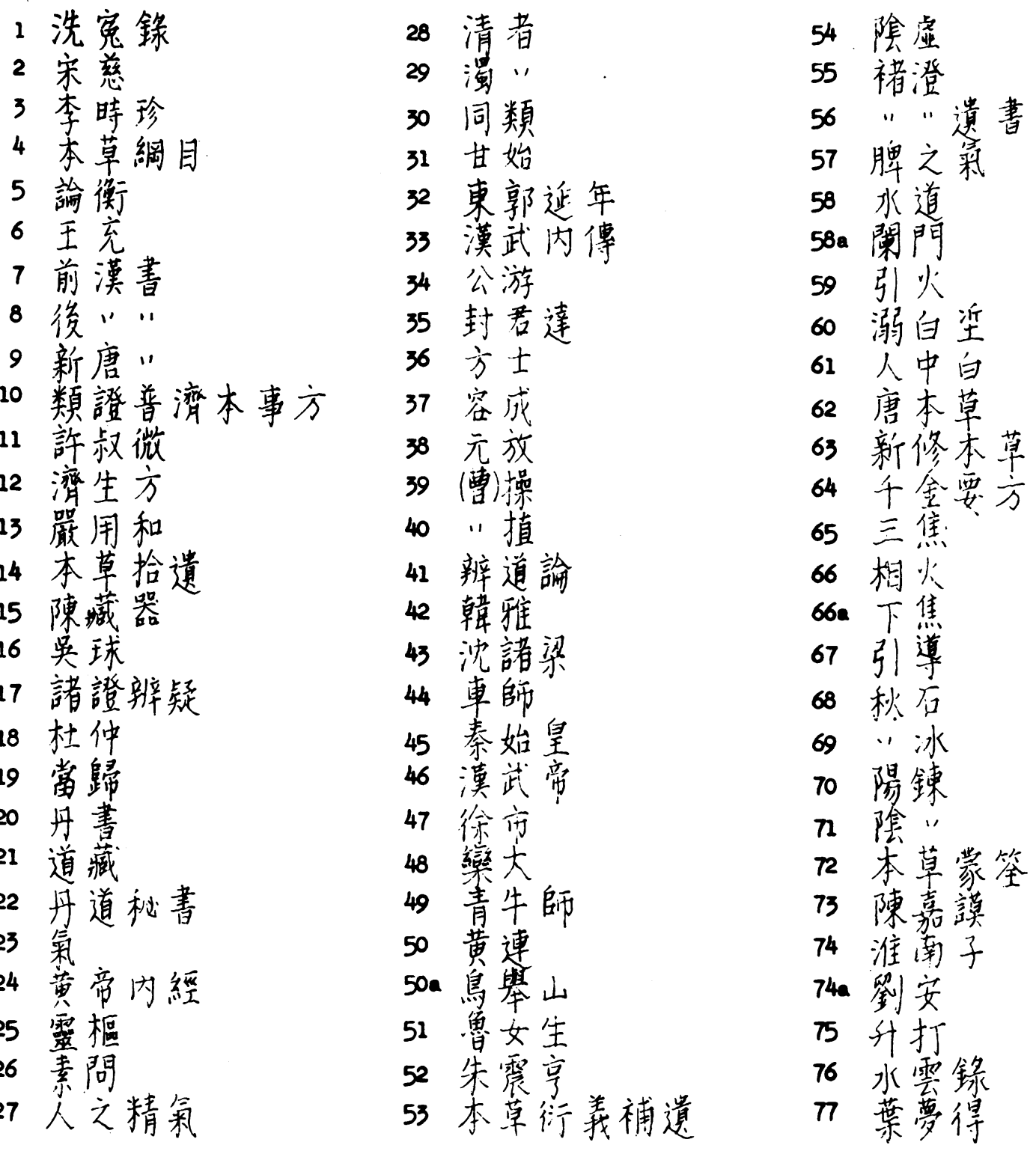




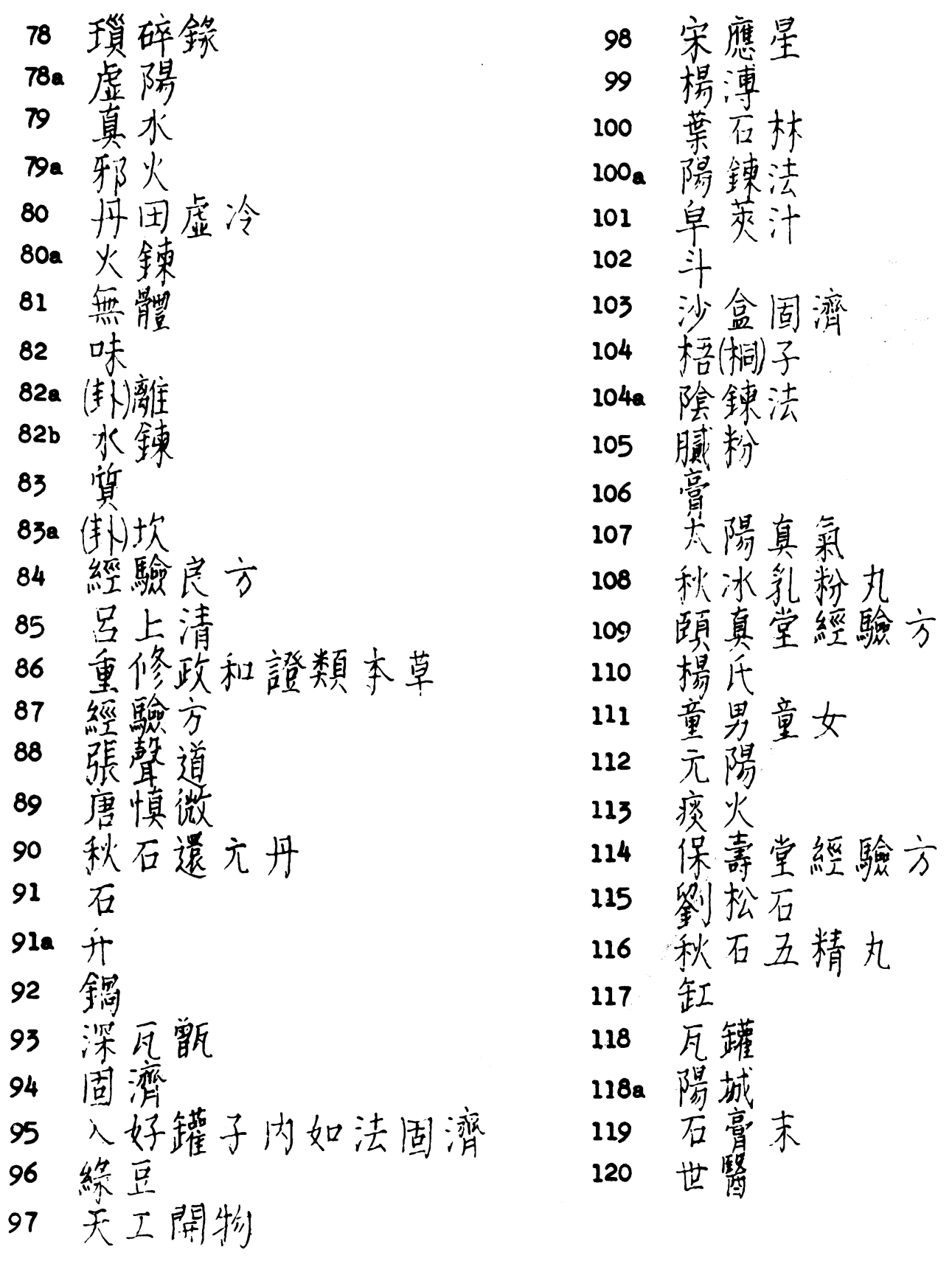




\section{Medieval Preparations of Urinary Steroid Hormones}

\section{BIBLIOGRAPHY}

Allen, E. (ed.), Sex and Internal Secretions; a Survey of Recent Research, Baltimore, Williams \& Wilkins, 1932.

Asсннегі, S., Weitere Untersuchungen über Hormone und Schwangerschaft; das Vorkommen der Hormone im Harn der Schwangeren, Arch. Gynäk, 1927, 132, I 79 .

Asquнeim, S., \& Zondex, B., Hypophysenvorderlappen Hormon und Ovarialhormon im Harn von Schwangeren, Klin. Wschr., 1927, 6, 1322.

Berendes, J., Die Pharmacie bei den alten Culturoölkern; historisch-kritische Studien, 2 vols., Halle, Tausch \& Grosse, 1891 .

Berthold, A. A., Transplantation der Hoden, Müller's Arch. Anat. Physiol. 1849, 16, 42. English trans. by D. P. Quiring, Bull. Hist. Med., 1944, 16, 399.

Brishagratna (Kaviraj), Kunja Lal Sharma, Susruta Samhita, 3 vols. with an index volume, pr. pr. Calcutta, 1907-18.

Breuer, H., \& Kassau, E., Eine Einfache Methode zur Isolierung von Steroiden aus Biologischen Medien durch Mikrosublimation, Proceedings of the Ist Int. Congr. Endocrinology, Copenhagen, 1960. Session xid, no. 561.

Brooks, Ghander MaG., Gilbert, J. L., Levey, H. A., \& Curtis, D. R., Humors, Hormones and Neurosecretions; the Origins and Development of Man's present Knowledge of the Humoral Control of Body Function, New York, New York State Univ., 1962.

BROWN-SÉUARD, C. E., Du rôle physiologique et thérapeutique d'un suc extrait de testicules d'animaux, d'après nombre de faits observés chez l'homme, Arch. Physiol. norm. Pathol., 1889, 21, 651.

Dorfman, R. I., \& Shipley, R. A., Androgens; their Biochemistry, Physiology and Clinical Significance, New York, Wiley, and London, Chapman \& Hall, I956.

Forbes, T. R., A[rnold] A[dolf] Berthold [1803 to $186 \mathrm{r}$ ] and the first endocrine experiment; some speculations as to its origin, Bull. Hist. Med., 1949, 23, 263.

Forke, A. (tr.), Lun Hêng, Philosophical Essays of Wang Chhung, vol. I, 1907, Shanghai, Kelly \& Walsh, London, Luzac, Leipzig, Harrassowitz. Vol. II, I9I I (with the addition of Reimer, Berlin). (Mitt. d. Seminar $f$. Orientalischen Sprachen, Beibände, ro, and 14). Photolitho repr., New York, Paragon, I962.

Giles, H. A., Chinese-English Dictionary, London, Quaritch, 1892. 2nd edn., 1912.

van Gulix, R. H., Sexual Life in Ancient China; a preliminary Survey of Chinese Sex and Society from ca. 1500 B.C. to A.D. I644, Leiden, Brill, I961.

Gunther, R. T. (ed.), The Greek Herbal of Dioscorides, illustrated by a Byzantine in A.D. 512, englished by John Goodyer in A.D. 1655, edited and first printed, 1933. pr. pr. Oxford, 1934. Photolitho. repr., New York, Hafner, 1959.

HalbaN, J., UUber den Einfluss der Ovarien auf die Entwicklung der Genitales, Mschr. Geburtsh. Gynäk, 1900, 12, 496.

Häussle R, E. P., UUber das Vorkommen von a-Follikelhormon (3-oxy-I 7 ketoI, 3, 5-oestratrien) in Hengsturin, Helv. chim. Acta, I934, I7, 531.

Ho Ping-Yü, \& NeEdham, Joseph (CAT), Theories of categories in early medieval Chinese alchemy, F. Warburg and Courtauld Insts., 1959, 22, 173.

Ho Ping-Yü, \& NeEdham, Joseph (LEG), The laboratory equipment of the early mediaeval chinese alchemists, Ambix, 1959, 7, 57.

Huard, P., \& Huang Kuang-Ming (M. Wong), La notion de cercle et la science chinoise, Arch. int. Hist. Sci., I956, 9, I I I.

KAPFERER, R., Der Blutkreislauf im altchinesischen Lehrbuch Huang Ti Nei Ching, Münch. med. Wschr., 1939 (no. 18), 7 18. 


\section{Lu Gwei-Djen and Foseph Needham}

KAssau, E., Charakterisierung einiger Steroidhormone durch Mikrosublimation, Dtsch. Apoth. Z., 1960, r 00 , 1102.

Knauer, E., Die Ovarientransplantation, Arch. Gynäk, rgoo, 60, 322.

Laufer, B., Sex transformation and hermaphrodites in ancient China, Amer. $\mathcal{F}$. phys. Anthrop., 1920, 3, 259.

Liang Po-Ghriang, Úberblick ü.d. seltenste chinesische Lehrbuch d.Medizin Huang Ti Nei Ching, Arch. Gesch. Med., 1933, 26, 121.

Liu Pen-Li, Hsing Shu-Ghieh, Li Gheeng-Ghriu, \& Ghang TaoChung, True hermaphroditism; a case report, Chin. med. F., 1959, 78, 449.

MaGovern, W. M., Early Empires of Central Asia, Chapel Hill, Univ. of North Carolina Press, 1939.

Mettler, Cecilia G., History of Medicine, Toronto, Blakiston, 1947.

Meyer, A. W., The Rise of Embryology, Palo Alto, Calif., Stanford Univ. Press, I939.

Needham, Joseph, $A$ History of Embryology, Cambridge Univ. Press, 1934. 2nd edn. revised with the assistance of A. Hughes, Abelard-Schuman, New York, 1959.

- et al. (SCC), Science and Civilisation in China, 7 vols. in to parts, Cambridge Univ. Press, 1954.

- \& LU GWer-DJEN (HYG), Hygiene and preventive medicine in ancient China, F. Hist. Med., 1962, 17, 429; abridged in Hlth. Educ. F., 1959, 17 , 170.

- \& Lu GweI-DJEN (PEC), Proto-Endocrinology in Medieval China (Stefan Milcu Festschrift), Bucarest, I 963 .

-, Wang Ling, \& Price, D. J. de S., Heavenly Clockwork; the Great Astronomical Clocks of Medieval China, Cambridge Univ. Press, 196o. (Antiquarian Horological Society Monographs, no. 1), prelim. pub. Antiquarian Horology, $1956, \mathrm{r}, 153$.

NeubuRGer, M., Théophile de Bordeu (1722 bis 1776) als Vorläufer d.Lehre von der inneren Sekretion, Wien. klin. Wschr., I91 I (pt. 2), 1367.

Oxanishi, Tameto, Sung I-chhien I Chi Khao (Comprehensive Annotated Bibliography of Chinese Medical Literature before the Sung Period). Peking, Jên-Min Wei-Sêng, 1958.

Read, Bernard E. (with Li Y Ü-Thien), Chinese materia medica; I-V, animal drugs, Peking nat. Hist. Bull., I 931, 5 (no. 4), 37-80. 6 (no. I), I-102. Sep. pub. French Bookstore, Peiping, 1931 (Chapters 50 to 52 of Pên. Tshao Kang $M u$ (The Great Pharmacopoeia) by Li Shih-Chen, I596; domestic animals, wild animals, rodentia and man).

Rolleston, Sir Humphrey, The Endocrine Organs in Health and Disease, with an Historical Review, London, 1936.

Rush, H. P., Biography of A. A. Berthold, Ann. med. Hist., 1929, 1, 208.

Russe LI, E. S., The Interpretation of Development and Heredity; a Study in Biological Method, Oxford, Clarendon Press, 1930.

Smith, F. Porter, Contributions towards the Materia Medica and Natural History of China, for the use of Medical Missionaries and Native Medical Students, Shanghai, Amer. Presbyt. Miss. Press, and London, Trübner, 1871 .

Suśruta-Samhita. See Bhishagratna.

Taki Mототаne, I Chi Khao (Comprehensive Annotated Bibliography of Chinese Medical Literature (Lost or Still Existing)) ca. 1825 pr. 1831, repr. Tokyo, 1933, and Chinese-Western Medical Research Society, Shanghai, 1936, with introduction by Wang Chi-Min. 


\section{Medieval Preparations of Urinary Steroid Hormones}

Teg gar t, F. J., Rome and China; A Study of Correlations in Historical Events, Berkeley, Calif., Univ. of California Press, 1939.

Tshao Yuan-Yü, Chung-Kuo Ku-Tai Chin-Tan-Chia ti Shê-Pei ho Fang-Fa (Apparatus and Methods of the Ancient Chinese Alchemists), Kho Hsüeh (Science, Shanghai), 1933, 17, 31. Reprinted in Wang Chin. Engl. précis by Barnes.

Veler, C. D., \& Doisy, E. A., Extraction of ovarian hormone from urine, Proc. Soc. exp. Biol. Med., 1928, 25, 806.

Wieger, L., Textes Philosophiques, Hsienhsien, Mission Press, 1930.

Windaus, A., Úber d.Entgiftung der Saponine durch Cholesterin, Ber. dtsch. chem. Ges., 1909, 42, 238.

Uber d. quantitative Bestimmung des Cholesterins und der Cholesterinester in einigen normalen und pathologischen Nieren, Z. physiol. Chem., 1910, 65, 110.

Wu Chнêng-Lo, Chung-Kuo Tu Liang Hêng Shih (History of Chinese Weights and Measures), Shanghai, Com. Press, 1937, 2nd ed. 1957.

Zonder, B., \& Aschreim, S., Hypophysenvorderlappen und Ovarium; Beziehungen der endokrinen Drüsen zur Ovarialfunktion, Arch. Gynäk, 1927, r30, 1. 